\title{
Design de interação no serviço público: Sugestão para gerenciamento de documentos
}

\author{
Tainara Serra Costa1;
}

Orientadora: Profa. Dra. Lívia Flávia de Albuquerque Campos²

resumo:

Instituições públicas são comumente sobrecarregadas de documentações complexas e sofrem com tecnologias e sistemas defasados, ocasionando experiências negativas às pessoas cidadãs e aos servidores. Segundo Pinto (2018), organizações públicas oferecem serviços capazes de impactar profundamente o bem-estar social e, a precariedade na prestação desses serviços pode dificultar a vida das pessoas cidadãs, além de incentivar o desperdício de recursos públicos. A precarização pode ser observada quando há sobrecarga de informações, ruídos e excesso de processos manuais para os trabalhadores, ocasionando, por conseguinte, sobrecarga cognitiva e estresse (IIDA, 2005). A capacidade de armazenamento humano e o estresse estão relacionados à perda de informações e, segundo Rogers et al (2013), nesses ambientes de trabalho as pessoas estão expostas a diferentes situações de sobrecarga cognitiva e é neste campo prático que o Design de Interação pode atuar, a fim de evitar sentimentos como frustração e aborrecimento ao lidar com informações. O Design de Interação, segundo Rogers (2013, p. 13), tem como sua principal preocupação "o desenvolvimento de produtos interativos eficientes, que consigam proporcionar boa experiência a seus usuários". Neste contexto, este trabalho compreenderá um estudo na Secretaria Municipal de Saúde (SEMUS), em São Luís, Maranhão. No dia a dia da referida secretaria circulam vários documentos administrativos, e dentre eles, encontram-se os processos administrativos e financeiros. A importância desses documentos consiste em atender com eficiência as demandas relativas à suprimentos de saúde, entretanto a secretaria enfrenta problemas referentes ao mau gerenciamento, o qual, além da lentidão no julgamento, impacta cognitiva e emocionalmente as pessoas que trabalham diretamente com esses documentos. Assim, a pesquisa faz-se relevante ao abordar quais recursos de Design de interação poderiam implementar melhorias práticas na gestão destes processos por intermédio do estudo de um produto interativo. Assim, lança-se mão da seguinte questão de pesquisa: "O Design de Interação pode viabilizar a melhoria no gerenciamento dos processos administrativos financeiros de instituições públicas, melhorando a experiência dos trabalhadores e reduzindo a carga cognitiva por intermédio de um produto interativo?". O estudo possui como objetivo, compreender se o Design de Interação pode viabilizar o acompanhamento dos processos administrativos financeiros de instituições públicas, a fim de proporcionar uma boa experiência às pessoas na execução das tarefas. 0 estudo se caracteriza como um estudo de caso de caráter exploratório. Pretende-se compreender os fenômenos que envolvem o objeto de estudo e, para viabilizar, serão utilizados métodos de observação participante (SANTOS, 2018), revisão da literatura, definição dos usuários, oficinas de cocriação utilizando técnicas de card sorting para construção da arquitetura da informação, entrevistas estruturadas e semi-estruturadas e coleta de dados através de gravações digitais e registros fotográficos (ROGERS, et al, 2013). A partir desse processo, espera-se construir colaborativamente um

\footnotetext{
1 http://lattes.cnpq.br/7844322449260865

2 http://lattes.cnpq.br/6231280946679281
} 
modelo de um produto interativo para acompanhamento desses documentos, representado e testado através de um wireframe de baixa fidelidade.

palavras-chave:

Design de interação; documentos; experiência do usuário; cognição humana

\section{Referências:}

IIDA, I. Ergonomia: Projeto e produção. 2. ed. São Paulo: Blucher, 2005.

ROGERS, Y.; SHARPE, H.; PREECE, J. Design de Interação: além da interpretação humanocomputador. Porto Alegre: Bookma, 2013.

SANTOS, A. Seleção do método de pesquisa: guia para pós-graduandos em design e áreas afins. Curitiba: Insight, 2018.

\footnotetext{
Espaço reservado para organização do congresso.
} 